\title{
Impact Assessment of Diesel Oil on the Zhe Oyster (Crassostrea plicatula) Using RAPD Analysis
}

\author{
Anglv Shen ${ }^{1}$, Chunyan $\mathrm{Ma}^{1}$ and Liu Shao ${ }^{2}$ \\ 1. East China Sea Fisheries Research Institute, Chinese Academy of Fishery Sciences, Shanghai 200090, China \\ 2. College of Fisheries and Life, Shanghai Ocean University, Shanghai 201306, China
}

Received: September 10, 2012 / Accepted: December 03, 2012 / Published: February 28, 2013

\begin{abstract}
The lethal and sublethal effects of oils on aquatic organisms have been widely investigated, but the potential molecular impacts of oils on aquatic organisms are remaining unclear now. In order to realize the effects of diesel oil on the Zhe oyster, the RAPD (random amplified polymorphic DNA) technique was used. RAPD is a useful assay procedure for the detection of genotoxin-induced DNA damage and mutations. In the present study, the Zhe oysters were exposed to diesel oil at different concentrations and for different exposure periods. The results showed that the DNA band change in RAPD profiles of oysters following diesel oil treatment included loss of normal DNA bands, the appearance of new DNA bands and variations in DNA intensity compared to oysters not exposed to diesel oil. The effects of changes to GTS (genome template stability) were time- and concentration-dependent, the GTS of $10 \mathrm{mg} / \mathrm{L}$ was $82.46 \%, 80.70 \%$ and $63.15 \%$ in the 8,16 and 32 days, the GTS of $20 \mathrm{mg} / \mathrm{L}$ was $75.44 \%, 71.93 \%$ and $56.14 \%$ in the 8,16 and 32 days, the GTS of $40 \mathrm{mg} / \mathrm{L}$ was $73.68 \%, 70.18 \%$ and $56.14 \%$ in the 8,16 and 32 days, respectively. The DNA polymorphisms detected by RAPD analysis could be used as a useful biomarker assay for the detection of genotoxic effects in diesel oil pollution on the oysters, and may be useful for environmental contamination risk assessment.
\end{abstract}

Key words: Diesel oil, Zhe oyster, RAPD, GTS, DNA damage, biomarker.

\section{Introduction}

Oysters, known as "milk of the sea", are considered delicious, nutritious and protein-rich, with a variety of unsaturated fatty acids, amino acids, vitamins and minerals. The Zhe oyster (Crassostrea plicatula) is an important member of China's coastal shellfish population and has a high economic value. It is considered a native species and is widely distributed in China, with the production of this oyster reaching $3.62 \times 10^{6}$ metric tons in 2002 , accounting for $37.6 \%$ of the total annual marine molluscan yield [1]. Bivalves (such as oysters) are widely used as sentinel organisms for monitoring the concentration of selected pollutants in coastal environments, such as heavy metals, organo-chlorine compounds and petroleum

\footnotetext{
Corresponding author: Liu Shao, Ph.D., lecturer, research field: marine environmental science. E-mail: s1317500@163.com.
}

hydrocarbons have long been recognized as the most deleterious contaminants to biota in the world's marine and estuarine waters, oysters have become good bio-indicators of environmental pollution in coastal and estuarine ecosystems because they, as filter feeders, bioaccumulate contaminants [2].

Over the past few decades, environmental contamination of water by oil has increased drastically. Oils (crude and fuel) spilled into the environment have multiple negative effects on aquatic organisms. Marine pollution due to oil and oil exploration pollution in ocean environments is an especially critical environmental concern [3]. Most previous studies have focused on the effects of oils on survival [4-11], morphological parameters [9, 11, 12], hematological physiological parameters [9, 12, 13], biochemical parameters [14-21] and histological parameters [13, 18, 19]. In addition, the molecular 
level changes of oil on aquatic organisms, such as micronucleus frequency, DNA repair, cytochrome P4501A, DNA adducts, DNA single strand breaks, microsatellite and AFLP loci were also studied [22-27].

Recently, the RAPD (random amplified polymorphic DNA) assay has been used to detect possible damage in the genomic DNA of organisms in ecotoxicology as a good biomarker [28-34]. The RAPD assay presents some advantages: RAPD assays lie in the PCR-based technique being easy identification of regions of amplification, deletion or rearrangement without prior information about the genome [34]; RAPD assays require very little source material and under certain circumstance and the analysis can also be performed non-destructively which can be useful for the screening of rare or valuable samples; RAPD technique is the high level of the overall sensitivity and relatively cheap and does not require the use of specialized and expensive equipment; RAPD method has the potential to detect a wide range of DNA damage [35]. However, there are no studies of oil contamination which use RAPD technology. In the present study, the principal objectives were to assess the impact of diesel oil contamination on the Zhe oyster in terms of DNA damage.

\section{Materials and Methods}

\subsection{Animals}

The oysters used in this study come from Xiangshan county $\left(29^{\circ} 21^{\prime} 16.50^{\prime \prime} \mathrm{S}, 121^{\circ} 58^{\prime} 46.72^{\prime \prime} \mathrm{W}\right)$, Zhejiang province, in the People's Republic of China. The shell length was $4.03 \mathrm{~cm} \pm 0.11 \mathrm{~cm}$, and the shell width was $2.65 \mathrm{~cm} \pm 0.19 \mathrm{~cm}$. The shell weight was $10.24 \mathrm{~g} \pm 0.54 \mathrm{~g}$, and the oysters have been domesticated two weeks before testing.

\subsection{Kinds of Fuel Oils and Preparation of Oil}

In the present study, the fuel oil used was No. -20 diesel oil. The oil was supplied by the Institute of
Waterborne Transportation Science, administered by the Ministry of Transportation of the People's Republic of China.

The authors prepared mixtures of oil from fuel oil samples in a 2,000 $\mathrm{mL}$ beaker using $2,000 \mathrm{mg}$ of diesel oil per Liter of clean seawater. The beaker was stirred continuously at a uniform speed for $30 \mathrm{~min}$ and then emulsified with an ultrasonic cleaner (DL-720A, made in Shanghai, China) for $8 \mathrm{~h}$. In this way, the authors simulated the effects of oil spilled in the sea. TPH (Total petroleum hydrocarbon) analysis was performed using UV spectrophotometry [36]. The various concentrations were then diluted.

\subsection{Experimental Design}

The oysters were exposed to four concentrations of mixtures of diesel oil $(0,10.0,20.0$ and $40.0 \mathrm{mg} / \mathrm{L})$ for 32 days. The oysters were fed with chlorella $200 \mathrm{~mL}$ a day, algae concentration was $3.5 \times 10^{6}$ cell $/ \mathrm{mL}$. There were 100 oysters in the $100 \mathrm{~L}$ tank per experimental group, $50 \mathrm{~L}$ mixtures of oil in each tank, and the temperature of the test was $24{ }^{\circ} \mathrm{C} \pm 2{ }^{\circ} \mathrm{C}$. Test water changed daily, and 10 oysters were taken from each group at 2, 8, 16 and 32 days. The samples were preserved with $95 \%$ ethanol and changed after three days. Each treatment was replicated three times.

\subsection{DNA Extraction and RAPD Analysis}

Genomic DNA was isolated from adductor muscle tissue (approximately $100 \mathrm{mg}$ ) using the standard phenol-chloroform method [37]. Subsequently, DNA was resuspended in a $50 \mu \mathrm{L}$ TE buffer $(2 \mathrm{~mL} 1 \mathrm{M}$ Tris,

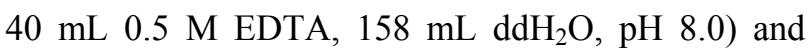
stored at $-20{ }^{\circ} \mathrm{C}$ until use.

The RAPD assays were performed on the GeneAmp PCR System 9700 (Applied biosystems, Invitrogen, USA) in $25 \mu \mathrm{L}$ of total volume containing approximately $2 \mu \mathrm{L}$ of genomic DNA (10 $\mathrm{ng} / \mathrm{L}), 1 \mu \mathrm{L}$ primers $(10 \mu \mathrm{mol} / \mathrm{L}), 1 \mu \mathrm{L}$ dNTP $(2.5$ $\mathrm{mmol} / \mathrm{L}$ each), $0.2 \mu \mathrm{L}$ Taq DNA polymerase (5 $\mathrm{U} / \mu \mathrm{L}), 10 \times$ reaction buffer $(100 \mathrm{mmol} / \mathrm{L}$ Tris- $\mathrm{HCl}$, 
pH 8.3, $15 \mathrm{mmol} / \mathrm{L} \mathrm{MgCl}_{2}, 500 \mathrm{mmol} / \mathrm{L} \mathrm{KCl}, 0.1$ mmol/L EDTA, $5 \mathrm{mmol} / \mathrm{L}$ DTT, 50\% glycerol, 0.1\% Triton X-100), $18.3 \mu \mathrm{L}$ distilled water. The 30 primers used were $10 \mathrm{bp}$ in length (S1-S30, Sangon Biotech, China). The RAPD protocol consisted of an initial denaturing step of $7 \mathrm{~min}$ at $94{ }^{\circ} \mathrm{C}$, followed by 45 cycles at $94{ }^{\circ} \mathrm{C}$ for $1 \mathrm{~min}$ (denaturation), $37{ }^{\circ} \mathrm{C}$ for $1 \mathrm{~min}$ (annealing) and $72{ }^{\circ} \mathrm{C}$ for $2 \mathrm{~min}$ (extension), with an additional extension period of $10 \mathrm{~min}$ at $72{ }^{\circ} \mathrm{C}$. For each amplification, a negative control was run for each primer. Reaction mixtures were stored at $4{ }^{\circ} \mathrm{C}$ prior to use. $3 \mu \mathrm{L}$ of each PCR product was electrophoresed in $1.5 \%$ agarose gels containing ethidium bromide for verifying the amplified fragment length with a DNA marker DL2000 (Takara, China). Images were captured using a high-resolution scan and digitalized images were counted directly for RAPD analysis.

\subsection{Estimation of GTS (Genomic Template Stability)}

Genomic template stability (\%) was calculated as $100-(100 a / n)$, where a represented RAPD polymorphic profiles detected in each sample treated and $n$ represented the number of total bands in the control. Polymorphism observed in RAPD profiles included disappearance of a normal band and appearance of a new band in comparison to control RAPD profiles [38]. To compare the sensitivity of this parameter, changes in this value were calculated as a percentage of their control (100\%). In addition, as the sampling time interval of 2 days is too short, there is no calculation of the GTS and compared with others.

\section{Results}

\subsection{TPH Concentrations}

Three different oil concentrations were set in this test, $10 \mathrm{mg} / \mathrm{L}, 20 \mathrm{mg} / \mathrm{L}$ and $40 \mathrm{mg} / \mathrm{L}$ (the actual concentration of oil), and with the corresponding TPH were $1.05 \times 10^{-2} \mathrm{mg} / \mathrm{L}, 2.10 \times 10^{-2} \mathrm{mg} / \mathrm{L}$ and $4.20 \times$ $10^{-2} \mathrm{mg} / \mathrm{L}$, respectively.

\subsection{Effect of Diesel Oil Stress on RAPD Profile}

Aimed at verifying the genetic effect of diesel oil contamination, the RAPD analysis was performed on DNA extracted from groups of 10 oysters from each replicate treated with diesel oil at concentrations of 0-40 mg/L. In total, 30 random 10-mer primers (Table 1) were used to amplify genomic DNA samples from the diesel oil-treated and control groups, and only 18 primers generated specific and stable results with a total number of 57 bands.

The RAPD fingerprints showed virtual differences between exposed oysters and control oysters. The changes included both loss and addition of bands compared with the control groups (Fig. 1). For example,

Table 1 Sequences of $\mathbf{3 0}$ primers used in this experiment.

\begin{tabular}{llll}
\hline No. of primers & Sequences $\left(5^{\prime} \rightarrow 3^{\prime}\right)$ & No. of primers & Sequences $\left(5^{\prime} \rightarrow 3^{\prime}\right)$ \\
\hline S1 & GTTTCGCTCC & S16 & TTTGCCCGGA \\
S2 & TGATCCCTGG & S17 & AGGGAACGAG \\
S3 & CATCCCCCTG & S18 & CCACAGCAGT \\
S4 & GGACTGGAGT & S19 & ACCCCGAAG \\
S5 & TGCGCCCTTC & S20 & GGACCCTTAC \\
S6 & TGCTCTGCCC & S21 & CAGGCCCTTC \\
S7 & GGTGACGCAG & S22 23 & TGCCGAGCTG \\
S8 & GTCCACACGG & S23 & AGTCAGCCAC \\
S9 & TGGGGGACTC & S24 & AATCGGGCTG \\
S10 & STGCTGGGAC & S26 & AGGGGTCTTG \\
S11 & GTAGACCCGT & S27 & GGTCCCTGAC \\
S12 & CCTTGACGCA & S28 & GAAACGGGTG \\
S13 & TTCCCCCGCT & S29 & GTGACGTAGG \\
S14 & TCCGCTCTGG & S30 & GGGTAACGCC \\
S15 & GGAGGGTGTT & & GTGATCGCAG \\
\hline
\end{tabular}



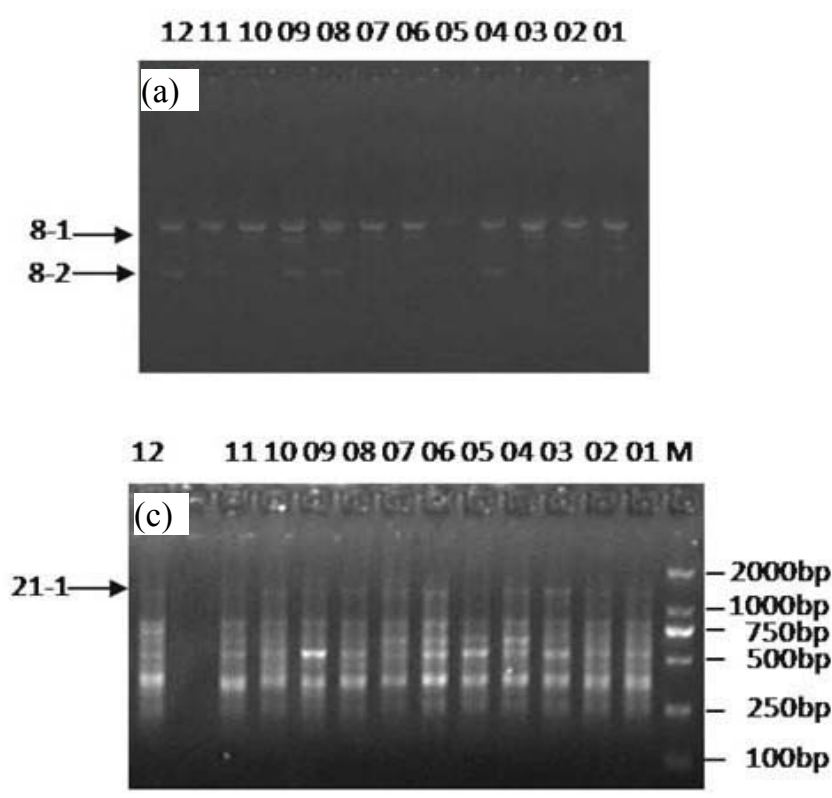

$121110090807060504030201 \mathrm{M}$
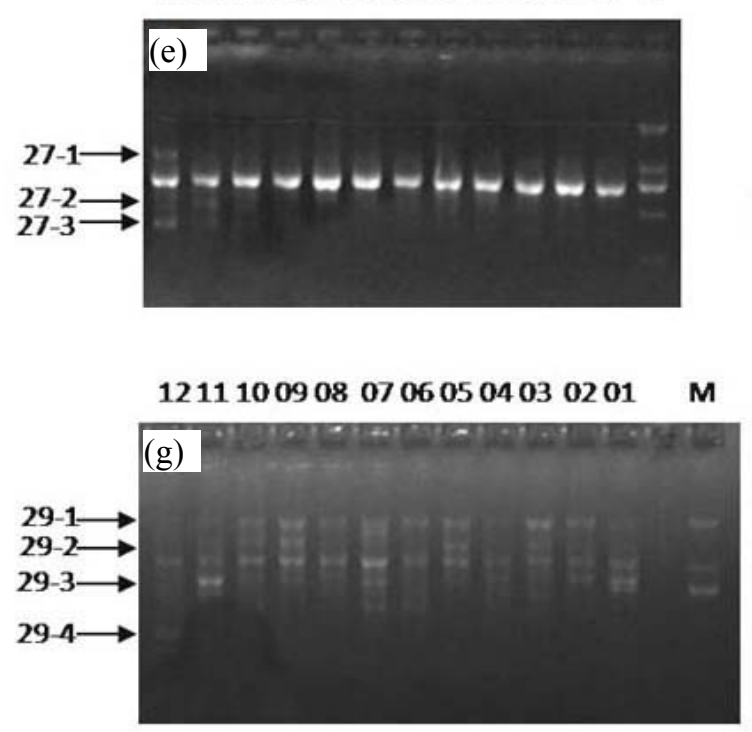

121110090807060504030201

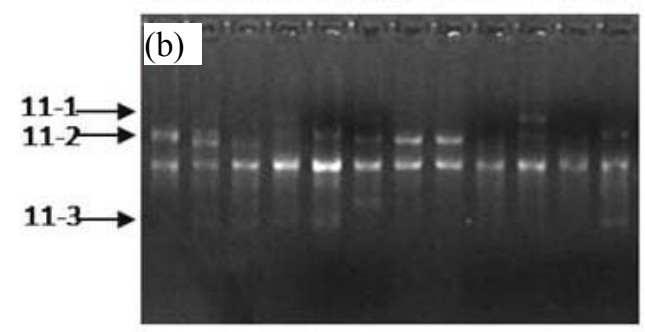

$121110090807060504030201 \mathrm{M}$

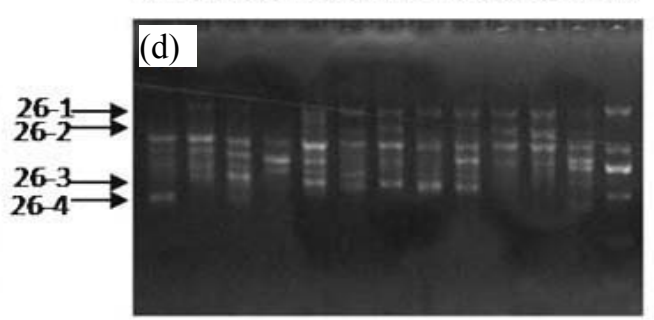

$121110090807060504030201 \mathrm{M}$

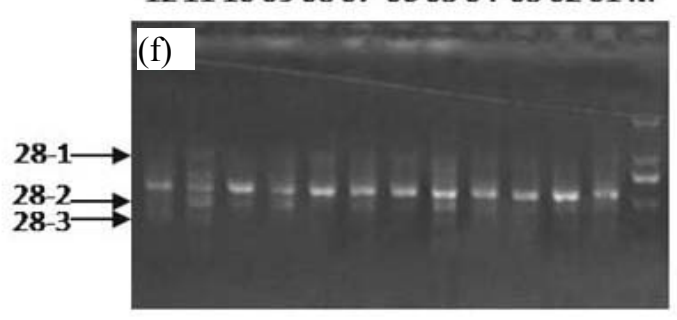

121110090807060504030201

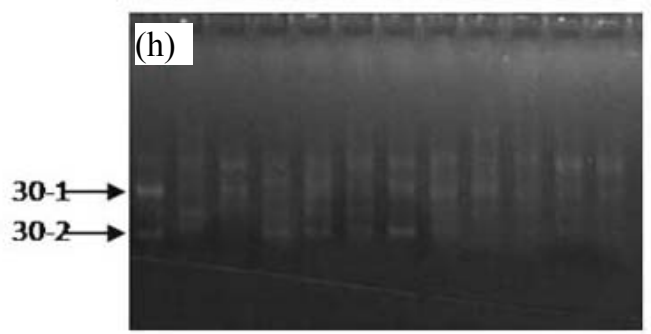

Fig. 1 RAPD profiles of genomic DNA from adductor muscle of the Zhe oyster exposed to varying concentrations of diesel oil. The RAPD patterns were obtained using 10-mer primers (a) S8, (b) S11, (c) S21, (d) S26, (e) S27, (f) S28, (g) S29, and (h) S30. In (a), (b), (c), (d), (e), (f), (g) and (h), numbers 1-12: control, $20 \mathrm{mg} / \mathrm{L}$ diesel oil exposed for 2 days, $40 \mathrm{mg} / \mathrm{L}$ diesel oil exposed for 2 days, $10 \mathrm{mg} / \mathrm{L}$ diesel oil exposed for 8 days, $20 \mathrm{mg} / \mathrm{L}$ diesel oil exposed for 8 days, $40 \mathrm{mg} / \mathrm{L}$ diesel oil exposed for 8 days, $10 \mathrm{mg} / \mathrm{L}$ diesel oil exposed for 16 days, $20 \mathrm{mg} / \mathrm{L}$ diesel oil exposed for 16 days, $40 \mathrm{mg} / \mathrm{L}$ diesel oil exposed for $16 \mathrm{days,}$ $10 \mathrm{mg} / \mathrm{L}$ diesel oil exposed for 32 days, $20 \mathrm{mg} / \mathrm{L}$ diesel oil exposed for 32 days, $40 \mathrm{mg} / \mathrm{L}$ diesel oil exposed for 32 days, respectively. M: molecular marker (2,000, 1,000, 750, 500, 250 and $100 \mathrm{bp}$ from top to bottom).

the primer S8 showed the number of disappearing RAPD bands was greater at several concentrations of 10-40 mg/L for different days of exposure (Fig. 1a 8-1, 8-2). The primer S11 showed the number of disappearing RAPD bands to be greater at several concentrations of 10-40 $\mathrm{mg} / \mathrm{L}$ for different exposed days (Fig. 1b 11-2, 11-3) as well. On the other hand, some figures showed changes in the addition of bands 
compared with the control groups, for instance, the primer S11 showed the number of adding RAPD bands was greater at several concentrations of 40 $\mathrm{mg} / \mathrm{L}$ exposed for 2 days (Fig. 1a 11-1). Other figures showed the same phenomena, as shown in Fig. 1e, Fig. 1g 29-4 and Fig. 1h 30-2.

\subsection{The Correlation between GTS and the Concentration of Diesel Oil}

In Table 2, the modifications in RAPD profiles are shown as a percentage of their control [37]. Changes in the RAPD patterns were expressed as decreases in GTS, a qualitative measure reflecting the obvious change to the number of RAPD profiles generated by the diesel oil-contaminated oysters. GTS values calculated for 18 primers are presented. The GTS value was decreased with the increased time of exposure. For instance, the GTS of $10 \mathrm{mg} / \mathrm{L}$ was $82.46 \%, 80.70 \%$ and $63.15 \%$ in the 8,16 and 32 days, respectively. There was significant linear relationship between GTS and the concentration of diesel oil. The regression equations were $y=98.6 x-0.228\left(R^{2}=\right.$ 0.9734, $y$ was GTS, and the $x$ was concentration), $y=$ $98.664 x-0.266\left(R^{2}=0.9769\right)$ and $y=94.299 x-$ $0.434\left(R^{2}=0.9023\right)$ at 8,16 and 32 days, respectively. In addition, although the GTS of $20 \mathrm{mg} / \mathrm{L}$ and 40 $\mathrm{mg} / \mathrm{L}$ were $56.14 \%$, the changes of RAPD profiles were different, with the appearance of 12 new bands in the $20 \mathrm{mg} / \mathrm{L}$ group, and the disappearance of 22 normal bands in the $40 \mathrm{mg} / \mathrm{L}$ group (Table 3). This effect will be used to evaluate damage to oysters in cases of oil spillage.

\section{Discussion}

\subsection{Application of RAPD Technique in Ecotoxicology}

In the field of ecotoxicology, RAPD studies describe the RAPD changes such as differences in band intensity as well as gain/loss of RAPD bands [35]. The RAPD assay has been used to determine the mutagenic effects of heavy metal pollution on the model plant (Arabidopsis thaliana), DNA from plants exposed to heavy metals solution displayed polymorphic bands which were not detectable in DNA of unexposed plants [29]. RAPD assay can be used to qualitatively detect the kinetics of $\mathrm{B}(\mathrm{a}) \mathrm{P}$-induced DNA effects in the water flea (Daphnia magna) exposed to $25 \mu \mathrm{g} / \mathrm{L}$ and $50 \mu \mathrm{g} / \mathrm{L}$ the main changes occurring in RAPD profiles produced by the population of Daphnia magna was a decrease and increase in band intensity compared with the control population [30, 31]. DNA changes in barley (Hordeum vulgare) seedlings induced by cadmium pollution using RAPD analysis and the results showed

Table 2 Changes of genomic template stability for all primers by diesel oil-contaminated oysters for different times (\%).

\begin{tabular}{lccc}
\hline No. -20 diesel oil concentration $(\mathrm{mg} / \mathrm{L})$ & $8 \mathrm{~d}$ & $16 \mathrm{~d}$ & $32 \mathrm{~d}$ \\
\hline 0 & 100 & 100 & 100 \\
10 & 82.46 & 80.70 & 63.15 \\
20 & 75.44 & 71.93 & 56.14 \\
40 & 73.68 & 70.18 & 56.14 \\
\hline
\end{tabular}

Table 3 Changes of total bands in control, polymorphic bands and varied bands in diesel oil-contaminated oysters.

\begin{tabular}{|c|c|c|c|c|c|c|c|}
\hline \multirow{3}{*}{ Exposure time (d) } & \multicolumn{7}{|c|}{ No. -20 diesel oil concentration $(\mathrm{mg} / \mathrm{L})$} \\
\hline & 0 & \multicolumn{2}{|r|}{10} & \multicolumn{2}{|c|}{20} & \multicolumn{2}{|r|}{40} \\
\hline & $a+b$ & $\mathrm{a}$ & $\mathrm{b}$ & $\mathrm{a}$ & $\mathrm{b}$ & a & $\mathrm{b}$ \\
\hline 8 & 57 & 5 & 5 & 6 & 8 & 8 & 7 \\
\hline 16 & 57 & 5 & 6 & 10 & 6 & 9 & 8 \\
\hline 32 & 57 & 11 & 10 & 12 & 13 & 3 & 22 \\
\hline
\end{tabular}

a: appearance of new bands; b: disappearance of normal bands; $a+b$ : polymorphic bands compared with control 
that the changes occurring in RAPD profiles of root tips following $\mathrm{Cd}$ treatment included variation in band intensity, loss of normal bands and appearance of new bands compared with the normal seedlings and the genomic template stability (a qualitative measure reflecting changes in RAPD profiles) was significantly affected at the above $\mathrm{Cd}$ concentration $[32,33]$. The similar effects was found in rice (Oryza sativa) contaminated by $\mathrm{Cd}$ [34]. Therefore, the comparison between "unexposed" and "exposed" genomes show that RAPD analysis can be used to evaluate how the environmental pollutants modify the structure of DNA in living organisms.

\subsection{RAPD Technique in Diesel Oil Pollution}

The RAPD assay presents many advantages and the RAPD assay is very reliable after optimization [31]. Therefore, the RAPD method has the potential to detect DNA damage (e.g. DNA adducts DNA breakage) as well as mutations (point mutations and large rearrangements) [35]. In the present study, the DNA damage in oysters stressed by the diesel oil was very clear, for example, we selected changes in the primers, as indicated by arrows, in comparison to a control group, which showed changes including loss and addition of bands compared with the control groups (Fig. 1). DNA damage leads to the instability of the genomic template. In this way, previous studies demonstrated that the GTS parameter picked up significant effects of $\mathrm{B}(\mathrm{a}) \mathrm{P}$ and $\mathrm{Cd}$ exposure [32-34, 38]. The RAPD assay was considered as a semi-quantitative assay [39] and another people use it as a qualitative rather than a quantitative method [31]. One problem is that the number of primers and characteristics of bands of RAPD for statistical significance in GTS. At present, there are 2-14 primers used in RAPD tests, obtaining a total number of bands ranging from 51-180 [30-34, 38]. In the present study, we selected 18 primers in RAPD tests and got 57 bands (Table 3). Therefore, the number of primers is not the most important factor, the total number of RAPD bands and polymorphic bands are the key factors in the present study. There is a clear tendency of the concentration of pollutants to be proportional to the number of RAPD polymorphic bands. For instance, different polymorphic bands were detected at each concentration of $\mathrm{Cd}$ for different primers, and the value of polymorphisms was $\mathrm{p}(\%)=$ $34.5 \%, 40.9 \%$ and $44.5 \%$ for 30,60 and $120 \mathrm{mg} / \mathrm{L} \mathrm{Cd}$, respectively [32]. In the present study, the authors found that not only exposure concentrations but also exposure times of pollutants were proportional to the number and polymorphisms of bands (Table 3 ). The number of RAPD polymorphic bands is exactly the number of loss and addition of bands compared with the control groups, and is the basis of the GTS calculation.

\section{Conclusion}

RAPD (Random amplified polymorphic DNA) is a useful assay procedure for the detection of genotoxin-induced DNA damage and mutations. This study showed that the DNA band changes in RAPD profiles of oysters following diesel oil treatment included loss of normal DNA bands, the appearance of new DNA bands and variations in DNA intensity compared to oysters not exposed to diesel oil. This study also showed that the change of GTS showed a dose-dependent and time-dependent tendency to the diesel oil. Therefore, a RAPD assay was quantitative and could be used as an investigation tool for environmental toxicology, as well as a useful biomarker.

\section{Acknowledgments}

This work was supported by the open fund of Laboratory of Marine Spill Oil Identification and Damage Assessment Technology (201104) and the Key Disciline Construction of Shanghai Education Commission (No. J50701). The authors thank Yamei Bi and Yong Zhang for assistance with sample collection and DNA extraction in this project. 


\section{References}

[1] Q. Li, W.G. Liu, K. Shirasu, W.M. Chen, S.X. Jiang, Reproductive cycle and biochemical composition of the Zhe oyster Crassostrea plicatula Gmelin in an eastern coastal bay of China, Aquaculture 261 (2006) 752-759.

[2] M.S. Jeng, W.L. Jeng, T.C. Hung, C.Y. Yuh, R.J. Tseng, P.J. Meng, et al., Mussel watch: A review of $\mathrm{Cu}$ and other metals in various marine organisms in Taiwan, 1991-98, Environmental Pollution 110 (2000) 207-215.

[3] A.S. Wernersson, Aquatic ecotoxicity due to oil pollution in the Ecuadorian Amazon, Aquatic Ecosystem Health and Management Society 7 (2004) 127-136.

[4] S.F. Hedtke, F.A. Puglisi, Short-term toxicity of five oils to four freshwater species, Archives of Environment Contamination and Toxicology 11 (1982) 425-430.

[5] M.G. Carls, S.D. Rice, J.E. Hose, Sensitivity of fish embryos to weathered crude oil: Part I. Low-level exposure during incubation causes malformations, genetic damage, and mortality in larval Pacific herring (Clupea pallasi), Environmental Toxicology and Chemistry 18 (1999) 481-493.

[6] C.A. Pollino, D.A. Holdway, Toxicity testing of crude oil and related compounds using early life stages of the crimson-spotted rainbowfish (Melanotaenia fluviatilis), Ecotoxicology and Environment Safety 52 (2002) 180-189.

[7] S. Bhattacharyya, P.L. Klerks, J.A. Nyman, Toxicity to freshwater organisms from oils and oil spill chemical treatments in laboratory microcosms, Environmental Pollution 122 (2003) 205-215.

[8] R.A. Khan, J.F. Payne, Influence of a crude oil dispersant, Corexit 9527, and dispersed oil on Capelin (Mallotus villosus), Atlantic Cod (Gadus morhua), Longhorn Sculpin (Myoxocephalus octodecemspinosus), and Cunner (Tautogolabrus adspersus), Bulletin of Environment Contamination and Toxicology 75 (2005) 50-56.

[9] M.Z. Vosylienė, N. Kazlauskienė, K. Jokšas, Toxic effects of crude oil combined with oil cleaner simper green on yolk-sac larvae and adult Rainbow Trout Oncorbyncbus mykiss, Envionmental Science Pollution Research International 3 (2005) 136-139.

[10] S. Shafir, J. Van-Rijn, B. Rinkevich, Short and long term toxicity of crude oil and oil dispersants to two representative coral species, Environmental Science and Technology 15 (2007) 5571-5574.

[11] N. Kazlauskiene, M.Z. Vosyliene, E. Ratkeuyte, The comparative study of the overall effect of crude oil an fish in early stages of development, in: P. Hlavinek (Eds.), Dangerous Pollutants (Xenobiotics) in Urban Water Cycle, Springer, Heidelburg, 2008, pp. 307-316.
[12] M. González-Doncel, L. González, C. Fernández-Torija, J.M. Navas, J.V. Tarazona, Toxic effects of an oil spill on fish early life stages may not be exclusively associated to PAHs: Studies with Prestige oil and medaka (Oryzias latipes), Aquatic Toxicology 87 (2008) 280-288.

[13] J.D. Simonato, C.L.B. Guedes, C.B.R. Martinez, Biochemical, physiological, and histological changes in the neotropical fish Prochiladus lineatus exposed to diesel oil, Ecotoxicology and Environment Safety 69 (2008) 112-120.

[14] M. Pacheco, M.A. Santos, Biotransformation, endocrine, and genetic responses of Anguilla anguilla L. to petroleum distillate products and environmentally contaminated waters, Ecotoxicology and Environment Safety 49 (2001) 64-75.

[15] F.I. Achuba, S.A. Osakwe, Petroleum-induced free radical toxicity in African catfish (Clarias gariepinus), Fish Physiology and Biochemistry 29 (2003) 97-103.

[16] J.F. Zhang, X.R. Wang, H.Y. Guo, J.C. Wu, Y.Q. Xue, Effects of water-soluble fraction of diesel oil on the antioxidant defenses of the goldfish, Carassius auratus, Ecotoxicology and Environment Safety 58 (2004) 110-116.

[17] C. Martínez-Gómez, J.A. Campillo, J. Benedicto, B. Fernández, J. Valdés, I. García, et al., Monitoring III biomarkers in fish (Lepidorhombus boscii and Callionymus lyra) from the northern Iberian shelf after the Prestige oil spill, Marine Pollution Bulletin 53 (2006) 305-314.

[18] C. Morales-Caselles, N. Jiménez-Tenorio, M.L. González de Canales, C. Sarasquete, T. Ángel DelValls, Ecotoxicity of sediments contaminated by the oil spill associated with the tanker "Prestige" using juveniles of the fish Sparus aurata, Archives of Environment Contamination and Toxicology 51 (2006) 652-660.

[19] I. Marigómez, M. Soto, I. Cancio, A. Orbea, L. Garmendia, M.P. Cajaraville, Cell and tissue biomarkers in mussel, and histopathology in hake and anchovy from bay of Biscay after the Prestige oil spill (Monitoring Campaign 2003), Marine Pollution Bulletin 53 (2006) 287-304.

[20] J.B. Damásio, C. Barata, A. Munné, A. Ginebreda, H. Guasch, S. Sabater, et al., Comparing the response of biochemical indicators (biomarkers) and biological indices to diagnose the ecological impact of an oil spillage in a Mediterranean river (NE Catalunya, Spain), Chemosphere 66 (2007) 1206-1216.

[21] C. Alonso-Alvarez, C. Pérez, A. Velando, Effects of acute exposure to heavy oil from the Prestige spill on a seabird, Aquatic Toxicology 84 (2007) 103-110.

[22] E. Aas, T. Baussant, L. Balk, B. Liewenborg, O.K. Andersen, PAH metabolites in bile, cytochrome P4501A 
and DNA adducts as environmental risk parameters for chronic oil exposure: a laboratory experiment with Atlantic cod, Aquatic Toxicology 51 (2000) 241-258.

[23] C.M. Couillard, A microscale test to measure petroleum oil toxicity to mummichog embryos, Environmental Toxicology 17 (2002) 195-202.

[24] R.F. Lee, J.W. Anderson, Significance of cytochrome P450 system reponses and levels of bile fluorescent aromatic compounds in marine wildlife following oil spills, Marine Pollution Bulletin 50 (2005) 705-723.

[25] C. Bolognesi, E. Perrone, P. Roggieri, A. Sciutto, Bioindicators in monitoring long term genotoxic impact of oil spill: Haven case study, Marine Environment Research 62 (2006) 287-291.

[26] B. Pérez-Cadahía, B. Laffon, V. Valdiglesias, E. Pásaro, J. Méndez, Cytogenetic effects induced by Prestige oil on human populations: The role of polymorphisms in genes involved in metabolism and DNA repair, Mutation Research 653 (2008) 117-123.

[27] P. Jaime, H. Quesada, E. Rolán-Alvarez, A. Caballero, Genetic impact of the Prestige oil spill in wild populations of a poor dispersal marine snail from intertidal rocky shores, Marine Pollution Bulletin 56 (2008) 270-281.

[28] C.W. Theodorakis, L.R. Shugart, Genetic ecotoxicology II : population genetic structure in mosquitofish exposed in situ to radionuclides, Ecotoxicology 6 (1997) 335-354.

[29] C. Conte, I. Mutti, P. Puglisi, A. Ferrarini, G. Regina, E. Maestri, et al., DNA fingerprinting analysis by a PCR based method for monitoring the genotoxic effects of heavy metals pollution, Chemosphere 37 (1998) 2739-2749.

[30] F.A. Atienzar, A.J. Evenden, A.N. Jha, M.H. Depledge, Use of the random amplified polymorphic DNA (RAPD) assay for the detection of DNA damage and mutations: Possible implications of confounding factors, Biomarkers 7 (2002) 94-101.

[31] F.A. Atienzar, A.N. Jha, The random amplified polymorphic DNA (RAPD) assay to determine DNA alterations, repair and transgenerational effects in $\mathrm{B}(\mathrm{a}) \mathrm{P}$ exposed Daphnia magna, Mutation Research 552 (2004) 125-140.

[32] W. Liu, P.J. Li, X.M. Qi, Q.X. Zhou, L. Zheng, T.H. Sun, et al., DNA changes in barley (Hordeum vulgare) seedlings induced by cadmium pollution using RAPD analysis, Chemosphere 61 (2005) 158-167.

[33] W. Liu, L. Zheng, P.J. Li, X.M. Qi, Q.X. Zhou, T.H. Sun, Effects of cadmium stress on DNA polymorphism of genome in barley seedlings, Journal of Agro-Environment Science 25 (1) (2006) 19-24. (in Chinese)

[34] W. Liu, Y.S. Yang, Q.X. Zhou, L.J. Xie, P.J. Li, T.H. Sun, Impact assessment of cadmium contamination on rice (Oryza sativa L.) seedlings at molecular and population levels using multiple biomarkers, Chemosphere 67 (2007) 1155-1163.

[35] F.A. Atienzar, A.N. Jha, The random amplified pokymorphic DNA (RAPD) assay and related techniques applied to genotoxicity and carcinogenesis studies: A critical review, Mutation Research 613 (2006) 76-102.

[36] L.S. Shang, Q. Sun, H.Z. Xu, Study on the determination of petroleum hydrocarbon in mussels by UV-spectrophotometry, Marine Environmental Science 16 (1) (1998) 62-65. (in Chinese)

[37] J. Sambrook, E.F. Fritsch, T. Maniatis, Molecular Cloning: A Laboratory Manual, 3rd ed., Cold Spring Harbor Laboratory Press, NY, 2001.

[38] F.A. Atienzar, M. Conradi, A.J. Evenden, A.N. Jha, M.H. Depledge, Qualitative assessment of genotoxicity using random amplified polymorphic DNA: Comparison of genomic template stability with key fitness parameters in Daphmia magna exposed to benzo[a]pyrene, Environmental Toxicology and Chemistry 18 (1999) 2275-2282.

[39] J. Welsh, D. Ralph, M. McClelland, DNA and RNA fingerprinting using arbitrarily primed PCR, in: M.A. Innis (Ed.), PCR Strategies, Academic Press, San Diego, 1995, pp. 249-276. 